\title{
Mineralizable Soil Nitrogen: Amounts and Extractability Ratios ${ }^{1}$
}

\author{
N. G. Juma AND E. A. PAUL ${ }^{2}$
}

\begin{abstract}
Studies were conducted on a ${ }^{15} \mathrm{~N}$-labeled Weirdale loam, a Dark Gray Chemozemic soil (Boralfic Boroll) to (i) determine the amounts of $\mathbf{N}$ released by several methods previously used to obtain an estimate of potentially mineralizable $\mathrm{N}$, (ii) determine their ${ }^{15} \mathrm{~N}$ enrichment and extractability ratios, and (iii) compare the results from the above with the $\mathrm{N}$ mineralized during incubation and $\mathrm{NH}_{4}^{+}$released by the chloroform fumigation incubation technique. The $\mathrm{NH}_{4}^{+}-\mathbf{N}$ accumulated during $10 \mathrm{~d}$ in fumigated soils accounted for $\sim 1 \%$ of total $N$, was highly labeled, and had extractability ratios of 6.6 to 7.4. These ratios were similar to ones obtained for $\mathrm{N}$ mineralized during incubation of unfumigated soils. Ammonium-N extracted with dilute acidic permanganate solution $\left(0.01 M \mathrm{KMnO}_{4}\right.$ in 0.1 or $0.5 M \mathrm{H}_{2} \mathrm{SO}_{4}$ ) accounted for 0.72 to $0.84 \%$ of total $\mathrm{N}$ and had extractability ratios ranging from 3.4 to 3.9. A stronger solution of acidic permanganate extracted more $\mathbf{N}$ that was less enriched. Dilute sulfuric acid extracted $\mathrm{NH}+$ and organic $\mathrm{N}$ that had extractability ratios of $<3$. Ammonium- $N$ released by autoclaving the soil accounted for $\sim 1 \%$ of total $N$ and had extractability ratios ranging from 0.6 to 0.9 . Acid hydrolysis showed that $72 \%$ of total $N$ was hydrolyzable, $32 \%$ was amino acid- $\mathrm{N}$ and $20 \%$ was $\mathrm{NH}_{+}^{+}$released on hydrolysis. The extractability ratio for $\mathrm{NH}_{4}^{+}$released on hydrolysis was 1.7 and was significantly $(P<0.01)$ greater than extractability ratios of hydrolyzable $N$ and amino acid- $N$. The similarity and high extractability ratios of $\mathrm{NH}_{+}^{+}$released after fumigation and $\mathrm{NO}_{3}^{-}-\mathrm{N}$ accumulating during aerobic incubation indicated that the fumigation extracted a biologically meaningful fraction. The biomass was responsible for only 15 to $25 \%$ of the net $N$ mineralized during a 12-week incubation. Results indicated that (i) extraction of a highly labeled $\mathbf{N}$ pool in soil can only partly explain the source of $\mathbf{N}$ being mineralized, (ii) $\mathbf{N}$ is mineralized from several pools, and (iii) there is a remote possibility that a single extractant can extract the variety of $\mathbf{N}$ compounds undergoing mineralization and immobilization in soil.
\end{abstract}

Additional Index Words: $\mathrm{N}_{\text {on }} \mathrm{N}$ supplying power, $\mathrm{N}$ availability ratios, active $\mathbf{N}$ phase, biomass $N$, nonbiomass active $N$, total $N$.

Juma, N.G., and E.A. Paul. 1984. Mineralizable soil nitrogen: Amounts and extractability ratios. Soil Sci. Soc. Am. J. 48:76-80.

$\mathrm{T}$ HE AMOUNT AND ISOTOPIC RATIO of organic $C$ and $\mathrm{N}$ compounds extracted from soil by various techniques can yield useful information on organic compounds undergoing mineralization. Comparison of ${ }^{14} \mathrm{C}$ or ${ }^{15} \mathrm{~N}$ enrichment of extracted compounds with that of $\mathrm{CO}_{2}-\mathrm{C}$ or $\mathrm{NO}_{3}^{-}-\mathrm{N}$ mineralized during incubation may indicate whether biologically meaningful fractions are extracted. Jenkinson (1968) showed that ${ }^{14} \mathrm{CO}_{2}-\mathrm{C}$ evolved from a fumigated soil had a higher specific activity compared with $\mathrm{C}$ extracted with cold $0.1 \mathrm{M} \mathrm{HCl}$, boiling saturated $\mathrm{CaSO}_{4}$ solution, or $0.05 \mathrm{M}$ $\mathrm{Ba}(\mathrm{OH})_{2}$. Also, reagents that were strongly hydrolytic or those that extracted humic materials yielded fractions that were relatively lightly labeled.

Chichester (1970) physically fractionated a ${ }^{15} \mathrm{~N}$ -

\footnotetext{
${ }^{1}$ Contribution from Univ. of Saskatchewan, Saskatoon, Journal Paper no. R357. Received 25 Feb. 1983. Approved 27 Sept. 1983.

2 Assistant Professor, Dep. of Soil Sci., Univ. of Alberta, Edmonton T6G 2E3, and Professor, Dep. of Plant and Soil Biology, Univ. of California, Berkeley, CA 94720 , respectively.
}

labeled soil, extracted the particle-size fractions with hot, dilute sodium pyrophosphate, and determined the atom \% excess of $\mathrm{N}$ compounds in the extract after acid hydrolysis. The enrichment of various $\mathrm{N}$ forms in all the particle-size fractions was lower than the enrichment of $\mathrm{N}$ mineralized during a 4-week incubation of the particle-size fractions. Legg et al. (1971) autoclaved a ${ }^{15} \mathrm{~N}$-labeled soil and found that the ${ }^{15} \mathrm{~N}$ enrichment of amino acids, amino sugars, and unidentified $\mathrm{N}$ in the $\mathrm{CaCl}_{2}$ extracts was lower than the enrichment of total $\mathrm{N}$ in plants grown in the same soil under greenhouse conditions. This implied that the selectivity of the extractants was poor from the standpoint of biologically available $\mathrm{N}$. In contrast, the $\mathrm{NH}_{4}^{+}$accumulated during a 10-d incubation of a fumigated soil had a similar ${ }^{15} \mathrm{~N}$ enrichment compared with the $\mathrm{NO}_{3}^{-}-\mathrm{N}$ accumulated during incubation (Amato and Ladd, 1980; Paul and Juma, 1981). The enrichment of these fractions was much higher than that of total $\mathrm{N}$ in soil. These observations are consistent with throse of Jenkinson (1968) and show that the microbial biomass is a source and sink for $C$ and $\mathrm{N}$ as well as part of the active $\mathrm{C}$ and $\mathrm{N}$ phase in soil.

Stanford and Smith (1978) found that the $\mathrm{NH}_{4}^{+}$released by partial oxidation of soil organic matter with dilute acidic permanganate solutions accounted for approximately one third to one half of the potentially mineralizable nitrogen, $\mathrm{N}_{\mathrm{o}}$. On the basis of the high correlation between the amount of $\mathrm{NH}_{4}^{+}$extracted and the $N_{0}$ of 62 soils, they concluded that the extracted $\mathrm{NH}_{4}^{+}$came from a soil fraction readily susceptible to biological mineralization. Further work is necessary to elucidate the source and nature of $\mathrm{N}$ compounds released during the various extraction techniques that try to mimic the action of microbial enzymes in soil.

The objectives of this study are (i) to determine the amount and isotopic ratio of $\mathrm{N}$ compounds extracted, with dilute $\mathrm{CaCl}_{2}$ after autoclaving the soil, with dilute acid and acidic permanganate solution, and after $6 M$ $\mathrm{HCl}$ hydrolysis; and (ii) to compare the ${ }^{15} \mathrm{~N}$ enrichment of $\mathrm{NO}_{3}^{-}-\mathrm{N}$ and biomass $\mathrm{N}$ with those of extracted $\mathrm{N}$.

\section{MATERIALS AND METHODS \\ Incubation Experiments}

The ${ }^{15} \mathrm{~N}$ enriched surface soil samples of a Weirdale loam, a Dark Gray Chernozem (Boralfic Boroll), were obtained in fall from a field trial. This had investigated the effects of aqua $\mathrm{NH}_{3}$ and urea, in the presence and absence of a nitrification inhibitor [4-amino-1,2,4-triazole, (ATC)] on $\mathrm{N}$ distribution after a wheat crop (Juma and Paul, 1983). The soil with a total $\mathrm{N}$ content of $0.44 \%$ and a pH of 7.4 (1:2.5 water suspension) was incubated at $34 \mathrm{kPa}$ of soil pore moisture tension and at $28 \pm 1{ }^{\circ} \mathrm{C}$ to obtain $\mathrm{CO}_{2}$ and $\mathrm{NO}_{3}-\mathrm{N}$ production during net mineralization.

\section{Analysis}

Nitrate $N$ During Incubation-The leaching incubation technique (Stanford and Smith, 1972) was used to determine 
$\mathrm{N}$ mineralized during incubation. The atom $\%{ }^{15} \mathrm{~N}$ abundance of the mineral $\mathrm{N}$ leached was determined.

Ammonium $N$ Extracted by Chloroform Fumigation Incubation Technique-Duplicate, 50-g moist soil samples (ODB) were fumigated with chloroform for $24 \mathrm{~h}$ in a desiccator, followed by evacuation of these vapors and subsequent incubation for $10 \mathrm{~d}$ at $28 \pm 1^{\circ} \mathrm{C}$. Ammonium-N was extracted with $2 \mathrm{M} \mathrm{KCl}$ and its atom $\%{ }^{15} \mathrm{~N}$ abundance was determined.

Biomass $\mathrm{N}=\left(\mathrm{NH}_{4}^{+}-\mathrm{N}\right.$ extracted after $\left.10 \mathrm{~d}\right) / k_{\mathrm{N}}$

where $k_{\mathrm{N}}$ was 0.28 (Paul and Voroney, 1980).

Extraction of Soil $\mathrm{N}$ by Autoclaving in Dilute $\mathrm{CaCl}_{2}-\mathrm{Ten}$ grams of ${ }^{15} \mathrm{~N}$ enriched soil from laboratory incubation experiments sampled at the start of the experiment were placed in each of the two $50-\mathrm{mL}$ polypropylene centrifuge tubes, and $25 \mathrm{~mL}$ of dilute $\mathrm{CaCl}_{2}(0.01 M)$ was added. The samples were autoclaved for $16 \mathrm{~h}$, cooled, and centrifuged (Stanford, 1968). The extract was saved, and the residue was washed twice with $25-\mathrm{mL}$ aliquots of dilute $\mathrm{CaCl}_{2}$. All extracts of each sample were pooled, and the volume was made up to $100 \mathrm{~mL}$. Two $20-\mathrm{mL}$ aliquots from the composite extract were anlayzed for $\mathrm{NH}_{4}^{+}-\mathrm{N}$ and its ${ }^{15} \mathrm{~N}$ abundance.

Extraction of Soil $N$ with Acid and Acidic Permanganate Solutions-The finely ground $(<100$-mesh particle size) soil samples $(2 \times 1 \mathrm{~g})$ from $\mathrm{NH}_{4} \mathrm{OH}+\mathrm{ATC}$ treatment were extracted with $25 \mathrm{~mL} \mathrm{H}_{2} \mathrm{SO}_{4}$ at $0.025,0.05,0.10,0.25$, and $0.5 \mathrm{M}$ (Stanford and Smith, 1978). Duplicate, $5 \mathrm{~mL}$-aliquots were analyzed for $\mathrm{NH}_{4}^{+}$and total $\mathrm{N}$. The ${ }^{15} \mathrm{~N}$ abundance was measured on the composite of four distillates. Organic $\mathrm{N}$ and its ${ }^{15} \mathrm{~N}$ enrichment was determined by difference between the above-mentioned analyses.

Acidic permanganate extractions were carried out on soil samples that were preextracted with either 0.1 or $0.5 M \mathrm{H}_{2} \mathrm{SO}_{4}$. The residue was first washed with $25 \mathrm{~mL}$ of deionized water and subjected to the following treatments:

1. The finely ground soil samples $(2 \times 1 \mathrm{~g})$ were extracted with $25 \mathrm{~mL}$ of acidic permanganate solutions made in $0.5 \mathrm{M} \mathrm{H}_{2} \mathrm{SO}_{4}$.

2. The finely ground soil samples were extracted with 25 $\mathrm{mL}$ acidic permanganate solutions made in $0.1 \mathrm{M}$ $\mathrm{H}_{2} \mathrm{SO}_{4}$.

3. The coarser samples $(<2-\mathrm{mm}$ particle size) were extracted with acidic permanganate solutions made in $0.5 \mathrm{M} \mathrm{H}_{2} \mathrm{SO}_{4}$.

The final $\mathrm{KMnO}_{4}$ solution strength was $0.01,0.02,0.04$ 0.10 , and $0.20 \mathrm{M}$ in all cases. Duplicate 5 -mL aliquots of extracts were anlayzed for $\mathrm{NH}_{4}^{+}-\mathrm{N}$. The atom $\%{ }^{15} \mathrm{~N}$ abundance was measured on the composite of four distillates.

Extraction of Soil $N$ after Acid Hydrolysis-The different forms of soil $N$ were determined as described below and their atom $\%{ }^{15} \mathrm{~N}$ abundance was determined.

Total Hydrolyzable $N$-Total hydrolyzable $N$ was determined by the method of Bremner (1965). Two 10-g freezedried, ground ( $<100$-mesh) soil samples were hydrolyzed with $6 \mathrm{M} \mathrm{HCl}(100 \mathrm{~mL})$ for $16 \mathrm{~h}$ under reflux. The mixture was filtered and the volume of hydrolyzate was made up to $200 \mathrm{~mL}$. A $100-\mathrm{mL}$ aliquot was neutralized to $\mathrm{pH} 6.5 \pm 0.1$ and the volume made to $200 \mathrm{~mL}$. Two $20-\mathrm{mL}$ aliquots were used for total $\mathrm{N}$ determination (Rennie and Paul, 1971).

Amino acid-N-Two $20-\mathrm{mL}$ aliquots of neutralized hy. drolyzate from each sample were used to determine the amino acid-N by the ninhydrin-ammonia method (Bremner, 1965).

Ammonium- $\mathrm{N}$ Released by $6 \mathrm{M} \mathrm{HCl} \mathrm{Hydrolysis-Two} \mathrm{20-}$ $\mathrm{mL}$ aliquots of neutralized hydrolyzate from each sample were used to determine $\mathrm{NH}_{4}^{+}-\mathrm{N}$ by steam distillation with $\mathrm{MgO}$ powder (Bremner, 1965).

Preparation of Samples for ${ }^{15} \mathrm{~N}$ Determination-Steam distillation was used in all $\mathrm{N}$ analyses. The distillate was collected in boric acid and titrated to $\mathrm{pH} 4.8$ with 0.025 or
$0.05 \mathrm{M} \mathrm{H}_{2} \mathrm{SO}_{4}$. The titrated sample was acidified $(0.2 \mathrm{~mL}$ of $0.025 \mathrm{M} \mathrm{H}_{2} \mathrm{SO}_{4}$ ) and concentrated to dryness in a sample evaporator (Brinkmann sample concentrator SC/24R; temperature set at $50^{\circ} \mathrm{C}$ ). If the sample had $<1 \mathrm{mg}$ of $\mathrm{N}$, it was spiked with $1 \mathrm{~mL}\left(1 \mathrm{mg} \mathrm{mL}^{-1}\right)$ of analytical-grade $\left(\mathrm{NH}_{4}\right)_{2} \mathrm{SO}_{4}-\mathrm{N}$ of known atom $\%$ abundance before concentrating the sample. Approximately $1 \mathrm{~mL}$ of deionized water was used to redissolve the salts. The samples were transferred with disposable glass Pasteur pipettes into 15 by 85 $\mathrm{mm}$ disposable culture glass tubes and dried at $90^{\circ} \mathrm{C}$. The tubes were capped with disposable tops for autoanalyzer vials. Analyses for ${ }^{15} \mathrm{~N}$ atom \% abundance were carried out on either an Atlas GD150 or Micromass 602E mass spectrometer.

Precision and Reproducibility of ${ }^{15} \mathrm{~N}$ Analysis-The ${ }^{15} \mathrm{~N}$ analysis of standard $\left(\mathrm{NH}_{4}\right)_{2} \mathrm{SO}_{4}$ showed that the results were reproducible with a standard deviation of \pm 0.00003 atom $\%{ }^{15} \mathrm{~N}$ abundance. The standard deviation of atom $\%{ }^{15} \mathrm{~N}$ of total $\mathrm{N}$ in the $\mathrm{NH}_{4} \mathrm{OH}$ treated Weirdale loam was 20 -fold greater $(0.3760 \mathrm{l} \pm 0.0006, n=8)$. This included the machine error as well as errors during Kjeldahl digestion, distillation, and sample preparation. Work in our laboratory has shown that there is more variability in amount of $\mathrm{N}$ measured as total $\mathrm{N}$ or mineral $\mathrm{N}$ compared with ${ }^{15} \mathrm{~N}$ analysis.

\section{RESULTS}

The Weirdale loam used in this investigation was obtained from one of the 20 sites in which ${ }^{15} \mathrm{~N}$-labeled fertilizer trials were carried out, and its behavior with respect to ${ }^{15} \mathrm{~N}$ dynamics was typical to the others (Paul and Rennie, 1977; Juma and Paul, 1983). The ${ }^{15} \mathrm{~N}$ labeled samples were treated by a number of extraction methods previously used in attempts to chemically define $\mathrm{N}_{0}$. The atom $\%{ }^{15} \mathrm{~N}$ excess of $\mathrm{N}$ compounds extracted by various methods can be compared directly or by using the extractability ratio (Legg et al., 1971):

$$
\text { Extractability ratio }=\frac{\stackrel{(\text { Tagged } N \text { extracted })}{\div}(\text { Total } N \text { extracted })}{\left(\begin{array}{c}
\text { Tagged total } N) \\
\div(\text { Total } N)
\end{array}\right.} .
$$

This simplifies to

$$
\text { Extractability ratio }=\frac{\begin{array}{c}
\text { atom } \%{ }^{15} \mathrm{~N} \text { excess } \\
\text { of extracted } \mathrm{N})
\end{array}}{\left(\begin{array}{c}
\text { atom } \%{ }^{15} \mathrm{~N} \text { excess } \\
\text { of total } \mathrm{N})
\end{array}\right.} .
$$

The lower limit of extractability ratios is zero and would be obtained if no labeled $\mathrm{N}$ was extracted. An extractability ratio $>1$ implies that $\mathrm{N}$ compounds extracted are relatively enriched in ${ }^{15} \mathrm{~N}$ compared with enrichment of total $\mathbf{N}$ in soil.

\section{Effect of Autoclaving}

The $\mathrm{NH}_{4}^{+}-\mathrm{N}$ extracted by autoclaving soils ranged from 49 to $66 \mu \mathrm{g} \mathrm{g}^{-1}$ of soil and accounted for 0.98 to $1.44 \%$ of total $\mathrm{N}$ (Table 1). The amount of $\mathrm{NH}_{4}^{+-}$ $\mathrm{N}$ extracted in the urea + ATC treatment was significantly lower $(P<0.01)$ compared with other treatments. The total $\mathrm{N}$ in the different treatments varied as the soil was sampled by depth of the A horizon. The atom \% excess of composite samples of four distillates ranged from 0.0056 to 0.0070 and was lower than that of total. $\mathrm{N}$ in soils. Thus, the extractability 
Table 1-Amounts and extractability ratios of $\mathrm{NH}_{4}{ }^{+}-\mathrm{N}$ extracted by autoclaving Weirdale loam soil.

\begin{tabular}{lcccc}
\hline & \multicolumn{4}{c}{$\mathrm{NH}_{4}^{+}-\mathrm{N}$ in $\mathrm{CaCl}_{2}$ extracts } \\
\cline { 2 - 5 } Treatment & $\mu \mathrm{g} \mathrm{g}^{-1}$ soil & $\begin{array}{c}\% \text { of } \\
\text { total N }\end{array}$ & $\begin{array}{c}\text { atom \% } \\
{ }^{10} \mathrm{~N} \text { excess } \dagger\end{array}$ & $\begin{array}{c}\text { Extractability } \\
\text { ratio } \neq\end{array}$ \\
\hline $\mathrm{NH}_{4} \mathrm{OH}$ & $63 \mathrm{a} \S$ & 1.44 & 0.0059 & 0.9 \\
$\mathrm{NH}_{4} \mathrm{OH}+\mathrm{ATC}$ & $66 \mathrm{a}$ & 1.30 & 0.0056 & 0.6 \\
Urea + ATC & $49 \mathrm{~b}$ & 0.98 & 0.0070 & 0.8 \\
\hline
\end{tabular}

†The composite of four distillates of each treatment was analyzed for ${ }^{16} \mathrm{~N}$ enrichment.

$\ddagger$ The atom $\%{ }^{10} \mathrm{~N}$ excess of total $\mathrm{N}$ in $\mathrm{NH}_{4} \mathrm{OH}-, \mathrm{NH}_{4} \mathrm{OH}+\mathrm{ATC}-$, and urea + ATC-treated Weirdale loam were $0.0065,0.0098$, and 0.0091 , re spectively.

\$ Group means were compared with Scheffe test. Group means followed by the same letter are not significantly different at $P<0.05$.

ratios ranged from 0.6 to 0.9 (Table 1). More unlabeled $\mathrm{NH}_{4}^{+}-\mathrm{N}$ was extracted by autoclaving the soil compared with labeled $\mathrm{N}$, which shows that this method does not selectively release $\mathrm{NH}_{4}^{+}$from ${ }^{15} \mathrm{~N}$ labeled organic $\mathrm{N}$.

\section{Extraction with Dilute Sulfuric Acid}

The amount of $\mathrm{NH}_{4}^{+}-\mathrm{N}$ extracted increased from 19 to $39 \mu \mathrm{g} \mathrm{g}^{-1}$ as the sulfuric acid concentration increased from 0.025 to $0.50 M$ (Table 2). This accounted for 0.38 to $0.76 \%$ of the total $\mathrm{N}$ in soil. The extractability ratios of $\mathrm{NH}_{4}^{+}$ranged from 0.6 to 0.7 . The amount of $\mathrm{NH}_{4}^{+}-\mathrm{N}$ extracted $(Y)$ by different concentrations $(X)$ of sulfuric acid could be described by the hyperbolic equation

$$
Y=40( \pm 2) \cdot X /[0.040( \pm 0.007)+X] .
$$

The figures in parentheses are standard errors of the parameter estimates, RMS $=13.7 \mu \mathrm{g} \mathrm{g}^{-1}$ of soil with $16 \mathrm{df}$.

The organic $\mathrm{N}$ extracted $(Y)$ ranged from 73 to 134 $\mu \mathrm{g}$ of $\mathrm{N} \mathrm{g}^{-1}$ of soil as the concentration $(X)$ of sulfuric acid increased (Table 2 ) and could be described as follows:

$$
Y=135( \pm 5) \cdot X /[0.020( \pm 0.003)+X] .
$$

The figures in parentheses are standard errors of parameter estimates; RMS $=9.6 \mu \mathrm{g} \mathrm{g}^{-1}$ of soil with 14 df. The organic $\mathrm{N}$ extracted accounted for 1.43 to $2.64 \%$ of total N. The extractability ratios of organic $\mathrm{N}$ decreased as the concentration of acid increased. Also, the amounts and extractability ratios of organic $\mathrm{N}$ extracted were greater than $\mathrm{NH}_{4}^{+}-\mathrm{N}$ extracted with dilute acid.

\section{Extraction with Acidic Permanganate}

The Weirdale loam, after extraction with 0.1 or $0.5 \mathrm{M}$ $\mathrm{H}_{2} \mathrm{SO}_{4}$, was washed with water and extracted with acidic permanganate solution. The $\mathrm{NH}_{4}^{+}$released due to partial oxidation was measured and its atom $\%{ }^{15} \mathrm{~N}$ abundance was determined. The amount of $\mathrm{NH}_{4}^{+}$released increased as the strength of $\mathrm{KMnO}_{4}$ increased. For example, the amount of $\mathrm{NH}_{4}^{+}-\mathrm{N}$ released increased from $42 \mu \mathrm{g} \mathrm{g}^{-1}$ at $0.5 M \mathrm{H}_{2} \mathrm{SO}_{4}$ plus $0.01 M$

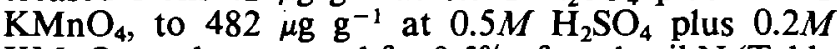
$\mathrm{KMnO}_{4}$, and accounted for $9.5 \%$ of total soil $\mathrm{N}$ (Table $3)$. The additional $\mathrm{NH}_{4}^{+}$extracted $(Y)$ was related to the strength of $\mathrm{KMnO}_{4}(X)$ as follows:

$$
Y=920( \pm 40) \cdot X /[0.186( \pm 0.014)+X] \text {. }
$$

Table 2-Effect of sulfuric acid concentration on the amounts

\begin{tabular}{|c|c|c|c|c|}
\hline \multirow{2}{*}{$\begin{array}{c}\text { Acid } \\
\text { concentration, } \\
\boldsymbol{M} \\
\end{array}$} & \multicolumn{4}{|c|}{ Extracted N } \\
\hline & $\mu \mathrm{g} \mathrm{g}^{-1}$ soil & $\begin{array}{l}\% \text { of } \\
\text { total N }\end{array}$ & $\begin{array}{c}\text { atom } \%{ }^{15} \mathrm{~N} \\
\text { excess } \dagger\end{array}$ & $\begin{array}{c}\text { Extractability } \\
\text { ratio }\end{array}$ \\
\hline & \multicolumn{4}{|c|}{$\underline{\mathrm{NH}_{4}+\mathrm{N}}$} \\
\hline 0.025 & 19 & 0.38 & 0.0062 & 0.6 \\
\hline 0.05 & 22 & 0.44 & 0.0063 & 0.7 \\
\hline 0.10 & 29 & 0.57 & 0.0061 & 0.6 \\
\hline 0.25 & 33 & 0.64 & 0.0057 & 0.6 \\
\hline \multirow[t]{2}{*}{0.50} & 39 & 0.76 & 0.0071 & 0.7 \\
\hline & \multicolumn{4}{|c|}{ Organic N } \\
\hline 0.025 & 73 & 1.43 & 0.0210 & 2.1 \\
\hline 0.05 & 109 & 2.16 & 0.0135 & 1.4 \\
\hline 0.10 & 105 & 2.07 & 0.0151 & 1.5 \\
\hline 0.25 & 125 & 2,46 & 0.0100 & 1.0 \\
\hline 0.50 & 134 & 2.64 & 0.0118 & 1.2 \\
\hline
\end{tabular}
and extractability ratios of $\mathrm{NH}_{4}{ }^{+} \cdot \mathrm{N}$ and organic $\mathrm{N}$ extracted from Weirdale loam soil.

† Atom \% ${ }^{16} \mathrm{~N}$ excess of the composite of four distillates.

The figures in parentheses are standard error estimates of the parameters; RMS $=10.9 \mu \mathrm{g} \mathrm{g}^{-1}$ of soil with 18 df. The extractability ratio of $\mathrm{NH}_{4}^{+}-\mathrm{N}$ decreased with increased $\mathrm{KMnO}_{4}$ concentration. However, the extractability ratio of 3.9 was obtained when the concentration of acidic permanganate was low. Thus, mild acidic $\mathrm{KMnO}_{4}$ solution released relatively highly labeled $\mathrm{NH}_{4}^{+}-\mathrm{N}$ compared with stronger $\mathrm{KMnO}_{4}$ solutions.

In the second series of experiments, the oxidation potential of acidic $\mathrm{KMnO}_{4}$ solutions was decreased by decreasing the strength of $\mathrm{H}_{2} \mathrm{SO}_{4}$ from 0.5 to $0.1 \mathrm{M}$. The weaker oxidizing solution decreased the amount of $\mathrm{NH}_{4}^{+}-\mathrm{N}$ extracted and up to $7.5 \%$ of total $\mathrm{N}$ was extracted (Table 3). The data could not be fitted to the hyperbolic equation. The extractability ratios of $\mathrm{NH}_{4}^{+}$decreased from 3.4 to 1.0 as the $\mathrm{KMnO}_{4}$ concentration increased. Thus, mild acidic permanganate solutions extracted highly labeled $\mathrm{NH}_{4}^{+}-\mathrm{N}$; however, regression analyses showed that extractability ratios were not significantly related to the concentration of the acidic permanganate.

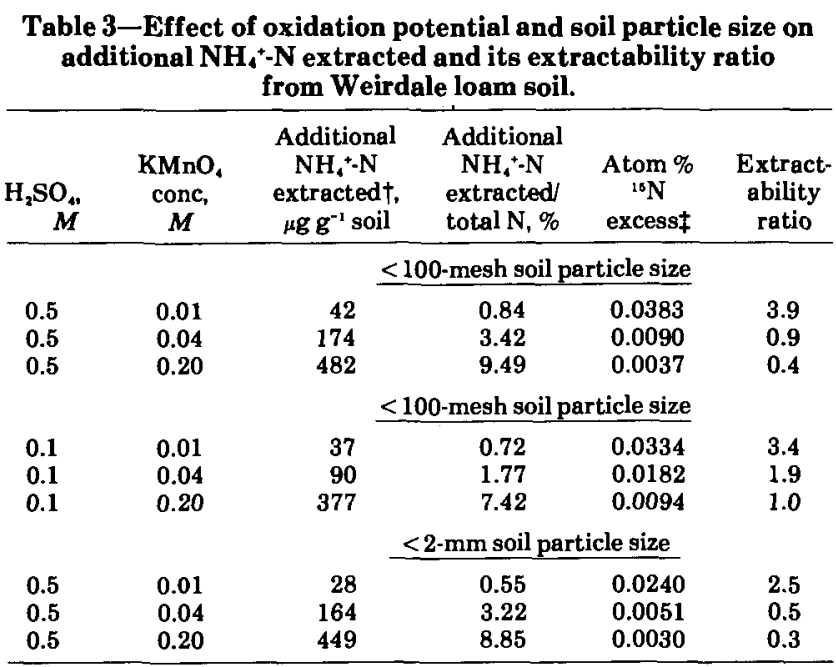

† Initially, the soil samples were extracted with either 0.5 or $0.1 \mathrm{M} \mathrm{H}_{2} \mathrm{SO}_{4}$ The residue was washed with water and reextracted with acidic permanganate solution. The data are reported additional $\mathrm{NH}_{4}^{+}-\mathrm{N}$ extracted ( $\mathrm{gg}^{-1}$ soil) due to acidic permanganate treatment.

$\mp$ Atom of ${ }^{16} \mathrm{~N}$ excess of composite of four distillates. 
Table 4-Amounts and extractability ratios of total hydrolyzable $\mathrm{N}$, amino acid-N and $\mathrm{NH}_{4}{ }^{+}$released on acid hydrolysis of Weirdale loam soil ( $\mathrm{NH}_{4} \mathrm{OH}$ treatment).

\begin{tabular}{|c|c|c|c|c|}
\hline Form & $\begin{array}{c}\text { Amount, } \\
\mu \mathrm{g} \mathrm{N} \mathrm{g}^{-1} \text { soil }\end{array}$ & $\begin{array}{c}\% \text { of } \\
\operatorname{total} N\end{array}$ & $\begin{array}{l}\text { Atom \% } \\
{ }^{16} \mathrm{~N} \text { excess }\end{array}$ & $\begin{array}{c}\text { Extractability } \\
\text { ratio }\end{array}$ \\
\hline Hydrolyzable $\mathbf{N}$ & 3142 a $\dagger$ & 72 & $0.0072 \mathrm{a}$ & 1.1 \\
\hline $\begin{array}{l}\text { Amino acid } \mathrm{N} \\
\mathrm{NH}+\text { released on }\end{array}$ & $1378 \mathrm{~b}$ & 32 & $0.0059 a$ & 0.9 \\
\hline $\begin{array}{l}\mathrm{NH}_{4}^{+} \text {released on } \\
\text { hydrolysis }\end{array}$ & & 20 & $00111 \mathrm{~h}$ & 17 \\
\hline Total N & $\begin{array}{r}876 \mathrm{c} \\
4368 \mathrm{~d}\end{array}$ & $\begin{array}{r}20 \\
100\end{array}$ & $0.0065 \mathrm{a}$ & 1.0 \\
\hline
\end{tabular}

$\dagger$ Group means $(n=4)$ were compared with Scheffe test. Group means followed by the same letter are not significantly different at $P<0.01$.

The soil particle size had little effect on the amount of $\mathrm{NH}_{4}^{+}-\mathrm{N}$ extracted. The relationship between the amount of $\mathrm{N}$ extracted $(Y)$ and concentration of acidic permanganate $(X)$ was

$$
Y=959( \pm 135) \cdot X /[0.234( \pm 0.052)+X] \text {. }
$$

RMS $=26.8 \mu \mathrm{g}$ of $\mathrm{N} \mathrm{g}^{-1}$ of soil with $18 \mathrm{df}$. Equation [4] is not significantly different from Eq. [3]. The extractability ratio of $\mathrm{NH}_{4}^{+}-\mathrm{N}$ extracted from the soil that had passed through a $2-\mathrm{mm}$ sieve was lower than from the soil that had passed through a 100-mesh sieve. This showed that increased amounts of labeled ${ }^{15} \mathrm{~N}$ compounds were extracted in the finer soil compared with the coarser one. The similarity of the amounts of $\mathrm{NH}_{4}^{+}-\mathrm{N}$ extracted suggests that the concentration of $\mathrm{KMnO}_{4}$ was limiting the amount of $\mathrm{NH}_{4}^{+}-\mathrm{N}$ extracted.

\section{Acid Hydrolysis}

About $72 \%$ of the total $\mathrm{N}$ was acid hydrolyzable (Table 4). Amino acid $\mathrm{N}$ accounted for $32 \%$ of total $\mathrm{N}$, whereas $\mathrm{NH}_{4}^{+}-\mathrm{N}$ released on hydrolysis accounted for $20 \%$. The extractability ratio of $\mathrm{NH}_{4}^{+}$released on hydrolysis was significantly higher $(P<0.01)$ than that of hydrolyzable $\mathrm{N}$ and amino acid $\mathrm{N}$. However, acid hydrolysis is a very drastic method to extract $\mathrm{N}$ compounds from soil and does not differentiate between $\mathrm{N}$ compounds present in the active organic phase from the passive $\mathrm{N}$ phase.

\section{Chloroform Fumigation-Incubation}

The atom $\%{ }^{15} \mathrm{~N}$ excess and the extractability ratios of $\mathrm{NO}_{3}^{-}-\mathrm{N}$ mineralized during the first 2 weeks and $\mathrm{NH}_{4}^{+}$extracted by the fumigation-incubation technique ranged from 6.1 to 8.2 for all the soils and were almost identical for each soil. Thus, the fumigation technique extracted a biologically meaningful active fraction. The extractability ratios of $\mathrm{NO}_{3}^{-}-\mathrm{N}$ produced during aerobic incubation and $\mathrm{NH}_{4}^{+}$released after fumigation and subsequent incubation declined slightly during incubation (data not shown). The biomass ${ }^{14} \mathrm{~N}$ size calculated by using $k_{\mathrm{N}}=0.28$ (Paul and Voroney, 1980) decreased by 15 to $26 \mu \mathrm{g} \mathrm{g}^{-1}$ during a 12-week incubation. At the same time, $\mathrm{NO}_{3}^{-}-\mathrm{N}$ accumulated ranged from 95 to $102 \mu \mathrm{g} \mathrm{g}^{-1}$. Thus, biomass $\mathrm{N}$ accounted for 15 to $25 \%$ of the net $\mathrm{N}$ mineralized.

\section{DISCUSSION}

Several different techniques were used in the present study to extract and measure the ${ }^{15} \mathrm{~N}$ enrichment of $\mathrm{N}$ compounds in soil. The $\mathrm{N}$ mineralized and mea-
Table 5-Comparison of the amounts of $\mathrm{NH}_{4}+$ released by chloroform fumigation incubation technique and $\mathbf{N}$ mineralized during 2 weeks for Weirdale loam soil.

\begin{tabular}{|c|c|c|c|c|}
\hline \multirow[b]{2}{*}{ Treatment } & \multicolumn{4}{|c|}{$\mathrm{N}$ form } \\
\hline & $\mu \mathbf{g}^{-1}$ soil & $\begin{array}{c}\% \text { of } \\
\text { total } \mathbf{N}\end{array}$ & $\begin{array}{l}\text { Atom \% } \\
{ }^{10} \mathrm{~N} \text { excess }\end{array}$ & $\begin{array}{c}\text { Extractability } \\
\text { ratio }\end{array}$ \\
\hline & \multicolumn{4}{|c|}{$\mathrm{NH}_{4}^{+}$during 10-d incubation of fumigated soil } \\
\hline $\begin{array}{l}\mathrm{NH}_{4} \mathrm{OH} \\
\mathrm{NH}_{4} \mathrm{OH}+\mathrm{ATC} \\
\text { Urea }+\mathrm{ATC}\end{array}$ & $\begin{array}{l}42 \mathrm{a} \dagger \\
50 \mathrm{~b} \\
51 \mathrm{~b}\end{array}$ & $\begin{array}{l}0.96 \\
0.98 \\
1.03\end{array}$ & $\begin{array}{l}0.043 \mathrm{a} \dagger \\
0.068 \mathrm{~b} \\
0.067 \mathrm{~b}\end{array}$ & $\begin{array}{l}6.6 \\
7.4 \\
7.4\end{array}$ \\
\hline Urea + ATC & \multicolumn{4}{|c|}{ N mineralized during 2 weeks in the laboratory } \\
\hline $\begin{array}{l}\mathrm{NH}_{4} \mathrm{OH} \\
\mathrm{NH}, \mathrm{OH}+\mathrm{ATC} \\
\text { Urea + ATC }\end{array}$ & $\begin{array}{l}16 a \ddagger \\
15 a \\
15 a\end{array}$ & $\begin{array}{l}0.36 \\
0.30 \\
0.30\end{array}$ & $\begin{array}{l}0.0408 \\
0.063 \\
0.074\end{array}$ & $\begin{array}{l}6.1 \\
6.4 \\
8.2\end{array}$ \\
\hline
\end{tabular}

$\dagger$ Mean of four analyses. Group means were compared with Scheffe test. Means followed by the same letter are not significantly different at $P$ $<0.01$.

$\ddagger$ Mean of six analyses.

$\$$ Atom \% ${ }^{10} \mathrm{~N}$ excess of the composite of six distillates.

Table 6-Amounts and extractability ratios of various $\mathbf{N}$ fractions of Weirdale loam soil.

\begin{tabular}{lcc}
\hline $\mathrm{N}$ form & $\begin{array}{c}\text { N extracted/ } \\
\text { total } \mathrm{N}, \%\end{array}$ & $\begin{array}{c}\text { Extractability } \\
\text { ratio }\end{array}$ \\
\hline $\begin{array}{l}\mathrm{N} \text { mineralized during 2-week } \\
\text { laboratory incubation }\end{array}$ & $0.30-0.36$ & $6.1-8.2$ \\
$\mathrm{NH}_{4}^{*}$ extracted by & & \\
Chloroform fumigation & & \\
$\quad$ incubation technique & $0.96-1.03$ & $6.6-7.4$ \\
$0.01 M$ KMnO, in $0.5 M \mathrm{H}_{2} \mathrm{SO}_{4}$ & 0.84 & 3.9 \\
$0.01 M$ KMnO, in $0.1 M \mathrm{H}_{2} \mathrm{SO}_{4}$ & 0.72 & 3.4 \\
$0.025 M \mathrm{H}_{2} \mathrm{SO}_{4}$ extractable organic $\mathrm{N}$ & 1.43 & 2.1 \\
$\mathrm{NH}_{4}{ }^{*}$ released on acid hydrolysis & 20 & 1.7 \\
$\mathrm{Hydrolyzable} \mathrm{N}$ & 72 & 1.1 \\
$\mathrm{Amino}$ acid N & 32 & 0.9 \\
$\mathrm{NH}_{4}^{*}$ extracted by autoclaving & $0.98-1.44$ & $0.6-0.9$ \\
\hline
\end{tabular}

sured as $\mathrm{NO}_{3}^{-}$during the laboratory incubation had the highest extractability ratios, ranging from 6.1 to 8.2 (Table 5). The $\mathrm{NH}_{4}^{+}$released by fumigating the soil had almost identical extractability ratios to $\mathrm{NO}_{3}^{-}$and accounted for $\sim 1 \%$ of the total $\mathrm{N}$. If the factor of 0.28 is used, the biomass size in the Weirdale loam could account for almost $4 \%$ of total N. Jansson (1958) calculated the size of the active $\mathrm{N}$ phase using isotopic dilution techniques and found that it accounted for 10 to $15 \%$ of soil organic N. Paul and Juma (1981) expanded this concept and divided the active $\mathrm{N}$ phase into biomass and nonbiomass active $\mathrm{N}$. The nonbiomass active $\mathrm{N}$ was $4 \%$ of the total $\mathrm{N}$ in the Weirdale loam.

Several extractants were used in an attempt to release portions of biomass or nonbiomass active $\mathrm{N}$ from soils. The $\mathrm{NH}_{4}^{+}$extracted with dilute acidic permanganate solution (after the initial acid extraction) accounted for $0.84 \%$ of the total $\mathrm{N}$ in soils and had extractability ratios that were almost one half of those of biomass or $\mathrm{NO}_{3}^{-}-\mathrm{N}$ (Table 6). The extractability ratios decreased as the oxidation potential increased (Table 3). Stanford and Smith (1978) observed that the additional $\mathrm{NH}_{4}^{+}$released by dilute acidic permanganate solution $\left(0.01 M \mathrm{KMnO}_{4}\right.$ in $\left.0.5 \mathrm{M} \mathrm{H}_{2} \mathrm{SO}_{4}\right)$ accounted for $22 \%$ of the $\mathrm{N}_{\circ}$ for 62 soils and suggested that this method should be used as a chemical index of $\mathrm{N}_{\mathrm{o}}$. The present investigation showed that this method indeed extracts a relatively enriched portion 
that accounted for $\sim 1 \%$ of soil organic matter. The initial acid extract released $39 \mu \mathrm{g}$ of $\mathrm{NH}_{4}^{+}-\mathrm{N} \mathrm{g}^{-1}$ of soil and $134 \mu \mathrm{g}$ of organic $\mathrm{N} \mathrm{g}^{-1}$ of soil, whereas $42 \mu \mathrm{g}$ of $\mathrm{NH}_{4}^{+}-\mathrm{N} \mathrm{g}^{-1}$ were extracted subsequently with dilute acidic permanganate solution. Dilute acid is known to lyse microbial cells and has been used to extract ATP from sediments (Lee et al., 1971). However, the dilute acid also extracted less labeled material, which caused the extractability ratio to be threefold to fourfold lower than that of biomass $\mathrm{N}$ (Table 6). The dilute acidic permanganate solution can possibly be used in a sequential extraction of organic $\mathrm{N}$ as it oxidizes and/or hydrolyzes a relatively ${ }^{15} \mathrm{~N}$ enriched fraction.

Acid hydrolysis with $6 \mathrm{M} \mathrm{HCl}$ is a drastic procedure that solubilizes a large portion of soil N. Hydrolyzable $\mathrm{N}$ accounted for $72 \%$ of soil $\mathrm{N}$ (Table 6 ). The extractability ratio of $\mathrm{N}$ compounds ranged from 0.9 to 1.7 and were similar to ones obtained by Chichester (1970) and Legg et al. (1971). Jenkinson (1968) also observed that the specific activity of ${ }^{14} \mathrm{C}$ decreased as more drastic methods were used to extract soil $C$. Thus, acid hydrolysis does not differentiate between active and recalcitrant $\mathrm{N}$ compounds in soil.

The $\mathrm{NH}_{4}^{+}$extracted by autoclaving the soil accounted for $1 \%$ of total $N$ and had very low extractability ratios. Stanford and Smith (1976) found that the $\mathrm{NH}_{4}^{+}-\mathrm{N}$ released by autoclaving the soil accounted for $\sim 25 \%$ of $N_{0}$. Autoclaving kills the microbial biomass but the labeled $\mathrm{N}$ was not released as $\mathrm{NH}_{4}^{+}$.

The atom $\%{ }^{15} \mathrm{~N}$ excess and extractability ratios of biomass $\mathrm{N}$ were much higher than any of the extractants used and were very similar to those of $\mathrm{NO}_{3}^{-}-\mathrm{N}$ produced during incubation (Table 6 ). The atom \% ${ }^{15} \mathrm{~N}$ excess of total $\mathrm{N}$ in the $\mathrm{NH}_{4} \mathrm{OH}, \mathrm{NH}_{4} \mathrm{OH}+\mathrm{ATC}$, and urea + ATC soil samples at the beginning of the laboratory incubation was $0.0065,0.0098$, and 0.0091 , respectively. ATC had caused a greater amount of fertilizer $\mathrm{N}$ to remain in organic and nonexchangeable $\mathrm{NH}_{4}^{+}$forms under field conditions (Juma and Paul, 1983 ). The atom $\%{ }^{15} \mathrm{~N}$ excess of biomass $\mathrm{N}$ and mineralized $\mathrm{N}$ in the $\mathrm{NH}_{4} \mathrm{OH}$ treatment was 0.040 and 0.043 , respectively, compared with 0.063 to 0.074 in the $\mathrm{NH}_{4} \mathrm{OH}+\mathrm{ATC}$ and urea + ATC treatments (Table $5)$. Thus, biomass $N$ and mineralized $N$ reflected the effect of ATC. In contrast, the enrichment of $\mathrm{NH}_{4}^{+}-\mathrm{N}$ extracted after autoclaving soil samples did not reflect the treatment effects.

The biomass was responsible for 15 to $25 \%$ of the net $\mathrm{N}$ mineralized during the 12 -week incubation. These results imply that (i) extraction of a highly labeled $\mathrm{N}$ pool in soil can only partly explain the source of $\mathrm{N}$ mineralized, (ii) $\mathrm{N}$ is being mineralized from several pools, and (iii) there is only a remote possibility that a single extractant could extract the variety of $\mathrm{N}$ compounds undergoing mineralization and immobilization in soil. Further research should focus on organic $\mathrm{N}$ pools in soil and the use of tracer techniques in conjunction with new extraction techniques to aid in separating organic $\mathrm{N}$ into biologically meaningful fractions and in unraveling the mechanisms and controls of the mineralization-immobilization processes in soil.

\section{ACKNOWLEDGMENTS}

We would like to thank the Canadian Wheat Board, the Natural Sciences and Engineering Research Council, and the Killam Memorial Trust for financial support; Mr. N. Binder for ${ }^{15} \mathrm{~N}$ mass spectrometer analyses, and Dr. W.B. McGill for his help and encouragement.

\section{REFERENCES}

1. Amato, M., and J.N. Ladd. 1980. Studies of nitrogen immobilization and mineralization in calcareous soils: $V$. Formation and distribution of isotope-labelled biomass during the decomposition of ${ }^{14} \mathrm{C}$ and ${ }^{15} \mathrm{~N}$-labelled plant material. Soil Biol. Biochem. 12:405-411.

2. Bremner, J.M. 1965. Organic nitrogen in soils. p. 93-149. In W.V. Bartholomew and F.E. Clark (ed.) Soil nitrogen. Am. Soc. of Agron., Inc., Madison, Wis.

3. Chichester, F.W. 1970. Transformations of fertilizer nitrogen in soil: II. Total and ${ }^{15} \mathrm{~N}$-labelled nitrogen of soil organomineral sedimentation fractions. Plant Soil 33:437-456.

4. Jansson, S.L. 1958. Tracer studies on nitrogen transformations in soil with special attention to mineralization-immobilization relationships. Lanthbrukshoegsk. Ann. 24:101-361.

5. Jenkinson, D.S. 1968. Studies on the decomposition of plant material in soil: II. The distribution of labelled and unlabelled carbon in soil incubated with ${ }^{14} \mathrm{C}$-labelled ryegrass. J. Soil Sci. 19:25-39.

6. Juma, N.G., and E.A. Paul. 1983. Effect of a nitrification inhibitor on $\mathrm{N}$ immobilization and release of ${ }^{15} \mathrm{~N}$ from nonexchangeable ammonium and microbial biomass. Can. J. Soil Sci. 63:167-175.

7. Lee, C.C., R.F. Harris, J.D.H. Williams, D.E. Armstrong, and J.K. Syers. 1971. Adenosine triphosphate in lake sediments: I. Determination. Proc. Soil Sci. Soc. Am. 35:82-86.

8. Legg, J.O., F.W. Chichester, G. Stanford, and W.H. DeMar. 1971. Incorporation of ${ }^{15} \mathrm{~N}$ tagged mineral nitrogen into stable forms of soil organic nitrogen. Soil Sci. Soc. Am. Proc. 35:273276.

9. Paul, E.A., and N.G. Juma. 1981. Mineralization and immobilization of nitrogen by microorganisms. In Terrestrial nitrogen cycles. F.E. Clark and T. Rosswall (ed.) Ecol. Bull. (Stockholm) 33: 179-195.

10. Paul, E.A. and D.A. Rennie 1977. Crop utilization and fate of fertilizer nitrogen in soil. p. 177-185. In Proc. of the 1977 Soil Fertility and Crops Workshop, Saskatoon. February. Pub. no. 328, Coop. Ext., Univ. of Saskatchewan, Saskatoon.

11. Paul, E.A, and R.P. Voroney. 1980. Nutrient and energy flow through soil microbial biomass. p. 215-237. In R.C. Ellwood et al. (ed.) Contemporary microbial ecology. Academic Press, Inc., New York.

12. Rennie, D.A., and E.A. Paul. 1971. Isotope methodology and techniques in soil-plant nutrition and plant physiology. Univ. of Saskatchewan Press, Saskatoon.

13. Stanford, G. 1968. Extractable organic nitrogen and nitrogen mineralization in soils. Soil Sci. 106:345-351.

14. Stanford, G., and S.J. Smith. 1972. Nitrogen mineralization potentials of soils. Soil Sci. Soc. Am. Proc. 36:465-472.

15. Stanford, G., and S.J. Smith. 1976. Estimating potentially mineralizable soil nitrogen from a chemical index of soil nitrogen availability. Soil Sci. 122:71-76.

16. Stanford, G., and S.J. Smith. 1978. Oxidative release of potentially mineralizable soil nitrogen by acid permanganate extraction. Soil Sci. 126:210-218. 